\title{
Research on Traditional Structural Aesthetics in Construction Realm in China
}

\author{
Sumei Yu \\ School of Art, Jiangsu University, Zhenjiang, China \\ Email: 346526213@qq.com
}

Received 14 July 2016; accepted 7 August 2016; published 10 August 2016

Copyright (C) 2016 by author and Scientific Research Publishing Inc.

This work is licensed under the Creative Commons Attribution International License (CC BY). http://creativecommons.org/licenses/by/4.0/

c) (i) Open Access

\begin{abstract}
The paper aims at indicating and demonstrating a kind of beautiful harmony in technology and art of excellent buildings of ancient China, through the analysis of cases of historic building up to the study of theoretical generalization. Any applicative, practical and durable building will conform to the simplicity of science and technology and harmony of design, and conform to the principle of beauty in the meantime. Architecture not only satisfies the need of functions, but represents the combination of skill and art, which is a sufficient integration of technology and art. The paper analyzes the relationship between technology and art of historic buildings in China by taking the typical examples of the Zhaozhou Bridge and the Hanging Temple of Hengshan, and clarifies the way of fusion between building and art, and indicates ways of fusion and reasons. In the last, the article proves the theory by the case of indoor decoration in modern building in order to defend mechanics and aesthetics in the modern buildings.
\end{abstract}

\section{Keywords}

The Chinese Ancient Architecture, Technology and Art, Mechanics and Aesthetics

\section{Introduction}

There are two reasons why the Chinese ancient architecture is self-contained. One is superior technology and containing high-tech; the other is the excellent skill and unique style. For example, the Zhaozhou Bridge (the Anji Bridge) built in Zhao County, Hebei province of Sui Dynasty, with a perfect combination of art and science and technology, goes through the attacks of natural hazards, such as floods, earthquakes, and never breaks off the services of the north-south transportations, which reflects the achievements of engineering mechanics in ancient China in the forefront of the world of bridge science. And it also represents the high harmony of skills and art of timber architectures, which shows the wonderful wisdom of ancients. 
The paper aims to discuss the art of design of ancient buildings, has a field visit of the ancient buildings and attempts to combine many subjects, such as architectural history, architectural technology, architectural philosophy, architecture art, science history, sociology, information technology. Wish to provide some useful ways to scientific study of modern buildings, raise more cares to historic buildings from people, and hope to have a good combination between traditional essence and modern skills in an extensive level.

\section{The Represent in the Combination of Mechanics and Aesthetics in the Design of Chinese Ancient Architecture}

In the time of spring and autumn period and the warring states period, dwellings were divorced from the original "cave". From the development of human, it indicates that the architecture develops with the development of human and human society. In the development of architecture, the functions, Material technical conditions and images of architecture become three elements of architecture [1].

In the early ancient time of China, there were books about the combination of building and art. The ancient book named Kaogongji. is the earliest official book recording all kinds of manufacturing technique and specification of quality of Social handicraft production handed from ancient times [2]. It was finished in the end of spring and autumn period to the warring states period, including from the urban planning to design of architecture, and the aspects from furniture to daily life.

\subsection{The Zhaozhou Bridge}

Before 1400 years, the Zhaozhou bridge (Figure 1) built under the bridge craftsman of Sui Dynasty, Li Chun, has a length of $64.4 \mathrm{~m}$, width of $9.6 \mathrm{~m}$ and a span of $37 \mathrm{~m}$. The Single span curved bridge, consisting of 28 relevantly independent arches, is used the creativity of open-spandrel design, 4 paratactic holes craved in the two shoulders of the great arch, which can increase the water pass, lighten the weight of bridge and save the material, in the meanwhile, it can also strengthen the stability of the bridge, being a typical represent of Chinese ancient bridge. In 1001, it was honored as "historic monument of international civil engineering" by American Society of Civil Engineers [3].

- The appearance is beautiful, and it uses the Tanzania arch structure, which changes the tradition of China's early semicircle arch, it has a large span, low deck of bridge, and is easy to drive. Furthermore, it is easy to build.

- It has a unique design. Setting two small arches in the sides of large arch can not only save the materials and lighten its weight but increase the beauty of its own, and it can also discharge the floods.

- It has the design of single hole, without pier in the center of river. The stress state of bridge is equal application of pressure, which is very ideal to the stone structure of good compressive performance.

The structure types of building according to the force situation can be divided into structure of framework, wall, barrel, grid, arch, cable and so on [4]. From the stress diagram of arch of the Zhaozhou bridge (Figure 2), we know that every press of the bridge of cable structure is in the state of average stress. Such design is

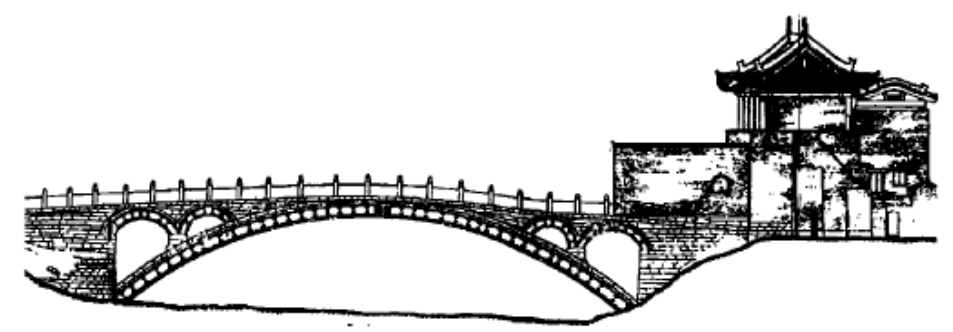

Figure 1. Profile of body of the Zhaozhou Bridge.

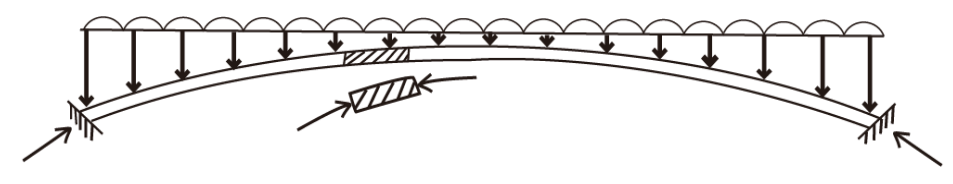

Figure 2. The stress diagram of arch of the Zhaozhou Bridge. 
obviously scientific. It can not only save the materials, lighten the weight of bridge, but also increase the ability of discharging floods. And it has beautiful model, which is a rare masterpiece in the history of building.

\subsection{The Hanging Temple of Hengshan Honored}

The Hanging Temple of Hengshan honored as "one of the world. We can see from the (Figure 3), was built in the late Northern Wei dynasty of 491. It is a typical building to combine the mechanics, aesthetics and religion together [5]. We will analyze the Pillar mechanics of temple from two aspects: 1 . pressure state of pillar; 2 . the stability of pillar.

- Stress state of the Hanging Temple's pillars

Analyze the stress state from a representative profile of the temple. We can see from Figure 4.

(1) The large part of long beam AC is placed on the rock mass of the chisel, with a cover on it. ZFDG constructed the whole structure is on the beam AC. The A part of beam and a small part form a short beam.

(2) The most part of above short beam AC can be seen as beam of rigid base, which cannot consider the deformation. The structure system forming the roof truss is safe.

- Stability of pillar

(1) The top of the long pillar $A B$ is braced in the part $A$, and the part of $B$ is braced on the stone. $A B$ will bear the short beam in the burn degree of $\mathrm{A}$, and if the part of $\mathrm{A}$ has large deformation, the top of the pillar has large pressure.

(2) The pillar of $\mathrm{AB}$ is a straight pole with stress in the center, taking charge of support and compression resistance.

This shows that the reason why the pillar of the temple goes through long-time test can still keep stable forever. There are 40 pavilions, making full use of mechanics principle, using stone to prop. Beam is up and down together, and the column connects from left to right, twists and turns, try to be unique [6].

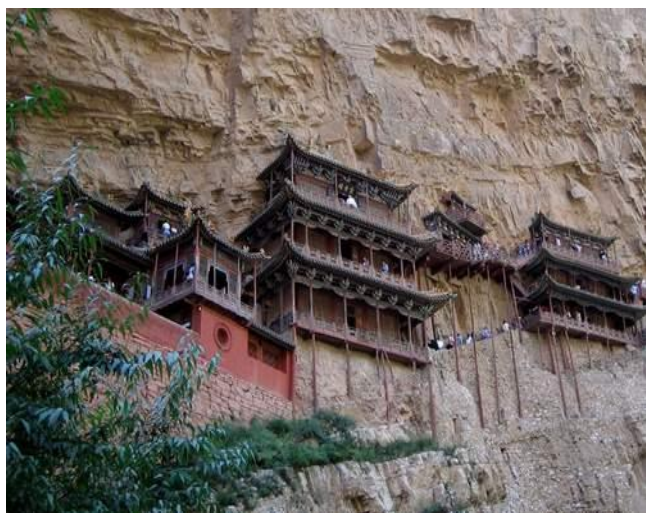

Figure 3. Profile of the Hanging Temple.

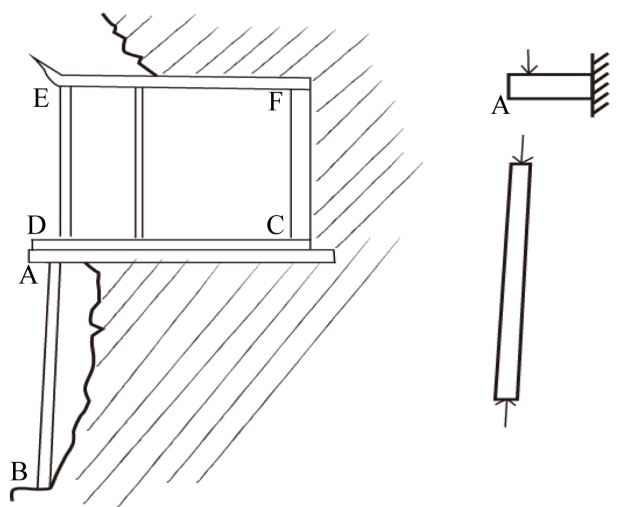

Figure 4. The stress diagram of the Hanging Temple. 

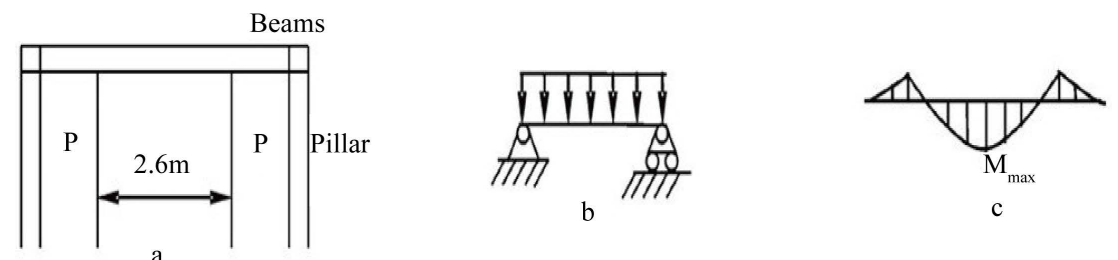

Figure 5. Figure of original design and the stress diagram.
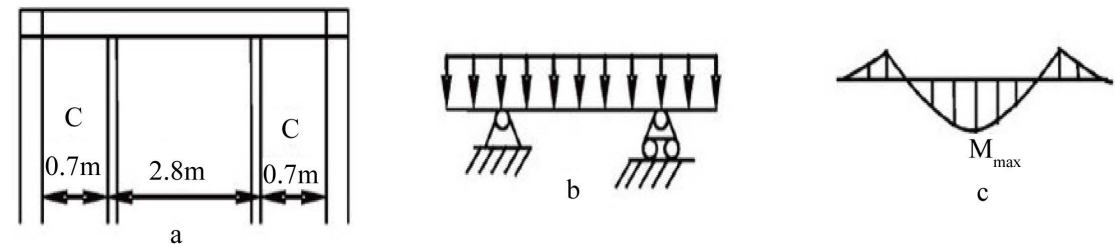

Figure 6. Figure of modification and the stress diagram.

\section{Problems in Modern Architecture}

According to the need of the test, we find an indoor decoration of housing in small residential area as the experimental subject. From the (Figure 5), we can see in the original design of building, partition $\mathrm{P}$ is designed between the main lobby and balcony, and the beam is spandrel girder. Now, when in the decoration design, many owners want to beat away the partition, and connect the main lobby and balcony together, thinking that it can make full use of space, and increase the area of main lobby, and also have better lighting. However, the party of construction refuses the scheme, because the partition A is spandrel girder, and beating away the partition will have an effect on safe of housing.

\section{The Solutions of Real Cases}

When the two parties can have an agreement about it, author through analyzing the relevant theory and calculation [7], comes up with a scheme that destroys the P, reserve a pillar C (Figure 6). So from after simplifying the stress state and bending moment diagram of the beam after simplify, and from the analysis of stress, the largest beam decreases from the original $\operatorname{Mmax}=0.845 q(\mathrm{Nm})$ to $\operatorname{Mmax}=0.735 q(\mathrm{Nm})$, the largest bending moment diagram decreases by $13 \%$, which not only cannot have effects on the safety of housing but have reasonable stress. And from the view of the aesthetics, the connection and independence of main lobby and balcony, with part in the combination, and combination in part, can enlarge the space, and be good to lightening, getting a harmony of mechanics and aesthetics. The scheme gets the praises of owners and the party of construction. And many owners use the scheme in the indoor decoration, and realize the perfect combination of science and art.

\section{Conclusion}

Architecture needs skills, and architecture represents the art, in the same time, there are double functions of matter and spirit. We can say that building is physical good and works of art. Building not only satisfies ask of function, but represent the combination of skill and art. The aim of design is to satisfy the basic meets and enjoying of human. Design should be complete combination of art, science and life, which is overall coordination of function, form, and skill, through the shape of matter conditions and the pursuit of the quality of spirit, and make creating humanized environment of living as the highest dream and extreme goal.

\section{References}

[1] Zheng, J. (2004) Theory of Modern Design. Packaging Engineering, 5, 23-25.

[2] Xu, Z.T. (2013) The Ancient Chinese Astronomy Dictionary. China Science and Technology Press, Vol. 3, $122-123$.

[3] Xia, L.G. and Yu, X.Y. (1992) Three Series of Relations between China and Foreign Countries Dictionaries. China-US Relations in the Dictionary, Dalian Press, Vol. 15, 341-315.

[4] Gu, J.J. (2004) Architecture and Design, Phoenix Publishing \& Media Group, Jiangsu Education Publishing House, 
Vol. 6, 42-43.

[5] Li, L.B. (2007) Engineering Mechanics. China Machine Press, Vol. 7, 259-262.

[6] Liang, S.C. (2005) History of Chinese Architecture. Baihua Literature and Art Publishing House, Vol. 3, 156-157.

[7] Long, Y. and Bao, S.H. (2000) Structural Mechanics. Beijing Higher Education Press, Vol. 9, 177-178.

\section{Submit or recommend next manuscript to SCIRP and we will provide best service for you:}

Accepting pre-submission inquiries through Email, Facebook, LinkedIn, Twitter, etc.

A wide selection of journals (inclusive of 9 subjects, more than 200 journals)

Providing 24-hour high-quality service

User-friendly online submission system

Fair and swift peer-review system

Efficient typesetting and proofreading procedure

Display of the result of downloads and visits, as well as the number of cited articles

Maximum dissemination of your research work

Submit your manuscript at: http://papersubmission.scirp.org/ 